\title{
Lymph node mapping in gastric cancer surgery: current status and new horizons
}

\author{
Barış Zülfikaroğlu'(D), Özlem Küçük²(D), Çigdem Soydal²(D), Mahir Özmen³ (D) \\ ${ }^{1}$ Clinic of General Surgery, Ankara Numune Training and Research Hospital, Ankara, Turkey \\ ${ }^{2}$ Department of Nuclear Medicine, Ankara University School of Medicine, Ankara, Turkey \\ ${ }^{3}$ Department of General Surgery, İstinye University School of Medicine, Istanbul, Turkey
}

\begin{abstract}
Gastric cancer (GC) remains one of the most important malignant diseases with significant geographical, ethnic, and socioeconomic differences in distribution. Sentinel lymph node (SLN) mapping is an accepted way to assess lymphatic spread in several solid tumors; however, the complexity of gastric lymphatic drainage may discourage use of this procedure, and the estimated accuracy rate is, in general, reasonably good. This study aimed at reviewing the current status of SLN mapping and navigation surgery in GC. SLN mapping should be limited to tumors clinically T1 and less than $4 \mathrm{~cm}$ in diameter. Combination SLN mapping with radioactive colloid and blue dye is used as the standard. Despite its notable limitations, SLN mapping and SLN navigation surgery present a novelty individualizing the extent of lymphadenectomy.
\end{abstract}

Keywords: Lymph node mapping, gastric cancer, surgery

Cite this article as: Zülfikaroğlu B, Küçük Ö, Soydal Ç, Özmen M. Lymph node mapping in gastric cancer surgery: current status and new horizons. Turk J Surg 2020; 36 (4): 393-398.

\section{Corresponding Author}

Barış Zülfikaroğlu

E-mail: zbaris61@gmail.com

Received: 16.08 .2020

Accepted: 27.08 .2020

Available Online Date: 29.12 .2020

○ Copyright 2020 by Turkish Surgical Society Available online at www.turkjsurg.com

DOI: $10.47717 /$ turkjsurg.2020.4932

\section{INTRODUCTION}

Gastric cancer (GC) remains one of the most important malignant diseases with significant geographical, ethnic, and socioeconomic differences in distribution (1). Gastric cancer is the second leading cause of death from malignant diseases worldwide, with especially high mortality rates in East, South, and Central Asia; Central and Eastern Europe; and South America. Gastric cancers are most frequently discovered in advanced stages, except in East Asia, where screening programs have been established. The prognosis of advanced GC remains poor, and curative surgery is regarded as the only option for cure. Early detection of resectable GC is extremely important for good patient outcomes; therefore, technologically sophisticated screening programs are needed. In the near future, however, improving the prognosis of advanced GC is necessary, which includes multimodality treatment using chemotherapy, radiotherapy, and surgery (2).

Sentinel lymph node (SLN) mapping is an accepted way to assess lymphatic spread in several solid tumors (i.e. breast cancer, vulvar cancer and melanoma). In an ideal world, SLN mapping should be as good as systematic lymphadenectomy in the identification of patients with lymph node dissemination, while reducing the morbidity associated with an extensive surgical procedure. In breast cancer and melanoma surgery, SLN biopsy has proven to be a valuable tool in lymph node mapping with a sensitivity of more than $95 \%$. When SLN biopsy is negative, lymphadenectomy can safely be omitted. Hence, SLN biopsy is now routinely practiced in these cancer types (3).

Although the complexity of gastric lymphatic drainage may discourage the use of this procedure, the estimated accuracy rate is, in general, reasonably good (4).

\section{Current Status of GC Surgery}

Gastric carcinoma shows a high tendency to lymph node metastasis. The risk of regional nodal involvement increases with deep penetration through the gastric wall, and the nodal extension of the cancer takes place gradually, radiating from 
primary location via the lymphatic system (4). Nodal metastases are observed in 3\%-5\% of the gastric carcinomas which are limited to the mucosa, $11 \%-25 \%$ of which extend to the submucosa, $50 \%$ of which reach the muscularis propria (T2), and $83 \%$ of which extend to the serosa (T3) (4). After curative radical resection, local recurrence is represented in $87.5 \%$ of cases by nodal metastases to local or regional lymph node stations (4).

The Japanese Classification of Gastric Carcinoma (Japanese Gastric Cancer Association, JGCA, 1998) (5) has defined 16 different lymph node stations (n) which drain the stomach (Figure 1).

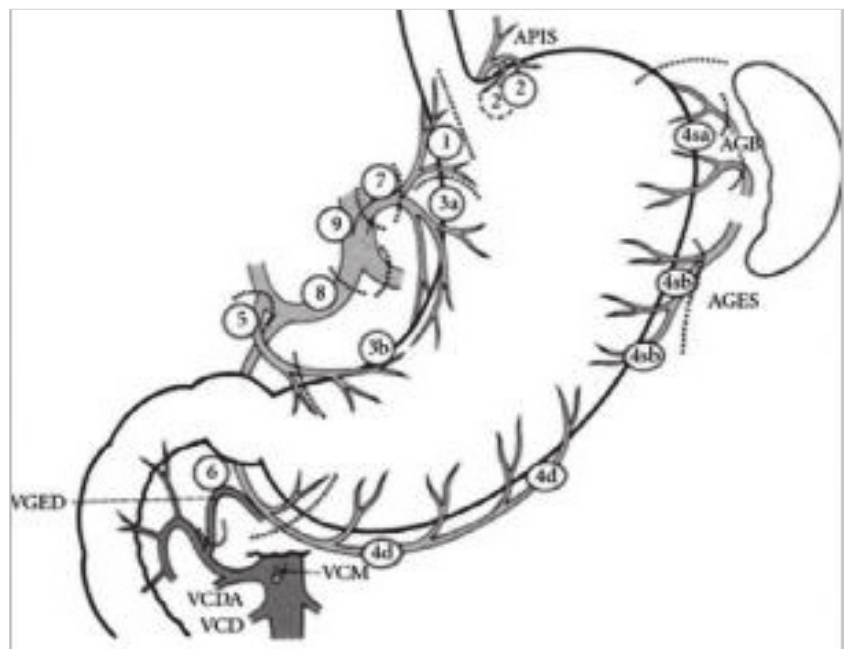

(a)

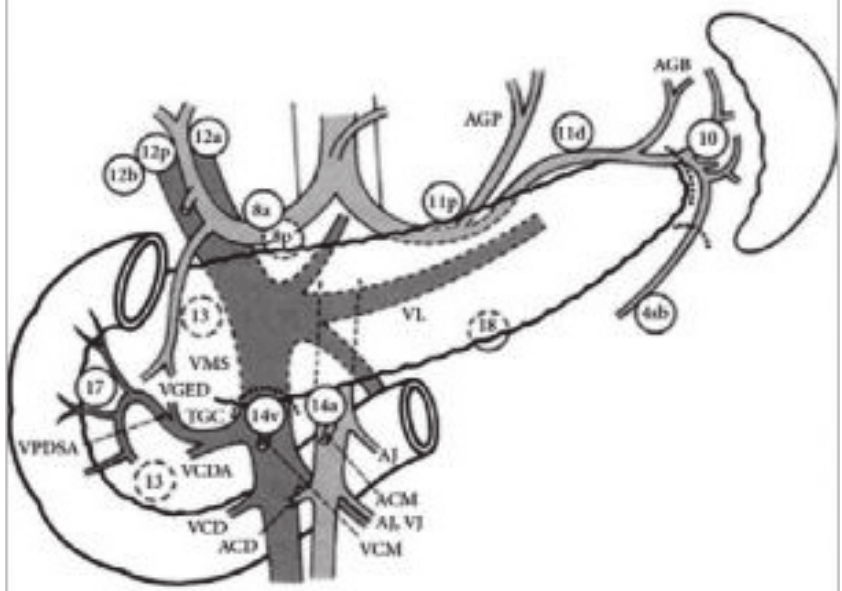

(b)

Figure 1. Lymph nodes that can be affected by dissemination of gastric carcinomas according to "Japanese Classification of Gastric Carcinoma. $2^{\text {nd }}$ English Edition".

ACD: A. colica dexira, ACM: A. colica media, AGB: A. gastricae breves, AGES: A. gstroepiploica sinistra, AGP: A. gastrica posterior, AJ: A. jejunalis, APIS: A. phrenica inferior sinistra, TGC: Truncus gastrocolicus, VCD: V. colica dextra, VCDA: V. colica dextra accessoris, VCM: V. colica media, VGED: V. gastroepiploica dextra, VJ: V. jejunalis, VMS: V. mesenterica superior VPDSA: V. pancreaticoduodenalis superior anterior.
These are subdivided into three levels according to their distance from the tumor, thus entailing three types of lymph node dissection (D) that can be associated to total or partial gastrectomy: $\mathrm{D} 1$, in which perigastric lymph nodes from $\mathrm{n} 1$ to $\mathrm{n} 6$ are removed (N1 level); D2, in which perigastric lymph nodes are removed as well as those located along the main arterial vessels from $n 7$ to n12 (N2 level); D3, in which stations n13 to n16 are removed, as well as those mentioned before (N3 level). During the 1960s, the Japanese authors first introduced D2 lymphadenectomy in patients with potentially curable advanced gastric carcinoma. Short- (6) and long-term (7) results of a comparative randomized controlled trial (RCT) between D1 and D3 (the D3 definition reported in did not include para-aortic lymph nodes) conducted on 221 patients who received curative surgery in a single institution were reported in 2004 and 2006. The authors concluded that D3 dissection improves survival rates, and suggested that it should be performed in specialized centers in order to limit the chance of postoperative complications. A RCT conducted by the East Asia Surgical Oncology Group in 2008 (8) compared the data of 135 patients treated with D2 gastrectomy, with 134 patients receiving D4 gastrectomy (in D4 dissection inter-, pre-, and latero-aortic lymph nodes of abdominal aorta as far as bifurcation are removed). The authors stated that D4 dissection is not the best treatment option for patients with gastric carcinoma, whereas D2 dissection is recommended if performed by experienced surgeons. The Dutch Gastric Cancer Group Trial (9), published in 2004, updated data on the survival of 711 patients previously enrolled in published RCTs. The authors concluded that D2 lymph node dissection can be recommended only if operative morbidity and mortality can be reduced. A further update of these data was published in 2010 (10), with a median follow-up of 15.2 years. The overall 15 -year survival was $21 \%$ after D1 resection and 29\% after D2 resection ( $P=0.34)$. Gastric cancer-related mortality rates resulted significantly higher in D1 than in D2 (41\% vs $37 \% ; P=0.01)$. The incidence of local recurrence $(D 1=22 \%$ vs $D 2=12 \%)$ and distant recurrence $(D 1=19 \%$ vs $D 2=13 \%)$ were different, albeit not significantly. Patients who received splenectomy and pancreatectomy had significantly lower overall survival rates in both D2 and D1 groups. On the other hand, patients who received D2 resection without pancreatico-splenectomy had a significantly higher overall 15-year survival compared to patients receiving D1 resection (35\% vs $22 \%, P=0.006$ ). The authors concluded that D2 resection should be considered the standard procedure to treat resectable gastric carcinoma. The Italian Gastric Cancer Study Group (11) published a multicentric RCT on 267 patients in 2010, comparing the short-term results of D1 and D2 gastrectomy for curable GC. Pancreaticosplenectomy was not considered a routine part of D2 gastrectomy, and the spleen and pancreas were removed only when indicated by the surgeon. The study did not show significant differences in terms of operative mortality, morbidity and duration of postoperative 
hospital stay. The authors concluded that D2 gastrectomy is a safe option to treat gastric carcinoma of Western patients as well, if it is performed in specialized centers (11).

In conclusion, in Western countries the prognostic value of D2 lymphadenectomy is still controversial, while in Eastern countries it is considered a standard procedure, likely to be further extended. Japanese authors do not even conduct RCT comparing D1 and D2 lymphadenectomies on the grounds that they consider D1 dissection unethical. Data indicate that D2 dissection is an adequate and potentially beneficial staging and treatment approach if operative mortality is avoided. Dissections extended to para-aortic lymph nodes do not show significant advantages in terms of survival. Splenectomy and distal pancreatectomy increase operative morbidity and mortality. D2 dissection is considered a difficult procedure and should be performed by experienced surgeons in specialized centers. Authors suggest that a surgeon should perform at least 200 gastrectomies under the supervision of an experienced surgeon before he can perform D2 lymph node dissections with acceptable morbidity and mortality rates (4). In Western countries, due to the lower incidence of gastric carcinoma, a surgeon is very unlikely to achieve such an experience (4).

\section{Rationale of SLN Mapping and Biopsy}

In GC, lymph node status is one of the most important prognostic factors. The extent of gastrectomy and lymphadenectomy is largely based on the likelihood of lymph node metastases to first- (N1) and second-tier (N2) lymph node stations. The applicability of SLN biopsy in GC has been studied in recent years in an effort to accurately predict metastasis to non-regional lymph nodes. The ultimate goal is to identify patients who truly need lymphadenectomy and to identify patients in whom lymphadenectomy can be omitted. Obviously, patients with suspicious or proven lymph node metastases are not eligible for SLN biopsy, and a routine D2 lymphadenectomy is deployed. Additionally, in patients with advanced tumors (T3 and more), SLN biopsy does not seem appropriate. These patients already have a high probability of having first- or second-tier lymph node metastases. Moreover, in advanced tumors, original lymphatic drainage routes might be obstructed or altered, resulting a lower accuracy of the SLN biopsy (1).

Surgical procedures for gastric cancer have been changing, for instance endoscopic mucosal or sub-mucosal resection, minimally invasive surgery and individualized management have become popular. For lymph node dissection, D2 lymph node dissection has been accepted standard procedure $(5,12)$. Since the early stage of GC has increased and SLN status is one of the most important prognostic factors, the extend of lymph node dissection is crucial during minimal invasive surgery. For this reason, the method to evaluate lymph node metastasis becomes more important. Behind the lymph node navigation method, complicated lym- phatic drainage of the gastrointestinal system, possibility of micro and/or skip metastases are other issues in SLN evaluation.

\section{Tracers}

Selection of optimal radioactive tracers for SLN mapping is an important issue. Although most studies focus on a single tracer, using a dual-tracer method (dye plus radioactive) would be more accurate in routine practice. Moreover, several controversies have remained such as the injection way or timing and volume of the tracer. Kitagawa et al. have shared their experience and reported that tin colloid particles migrates to SLN within 2 hour and remains about 20 minutes. They have also recommended endoscopic or laparoscopic injection (13) and (14) suggested that technetium-99m tin colloid is recommended as an optimal tracer for SLN mapping for gastric cancer.

Peparini (15) has suggested that advances in imaging technologies could allow a more accurate preoperative detection of SLN than the current dye- or radio-guided methods. Moreover, new dye-guided intraoperative technologies might revolutionize the SLN mapping procedure in gastrointestinal cancers. Indocyanine green (ICG) infrared or fluorescence imaging may identify a higher number of SLN than radio-guided methods because the particle size of the dyes is smaller than that of radioactive colloids. In GC, ICG infrared imaging is a useful tool in the laparoscopic detection of SLN. ICG fluorescence imaging is feasible even by preoperative ICG injection at, for instance, 1 or $3 \mathrm{~d}$ before surgery; it is also feasible in laparoscopy-assisted gastrectomy via a small laparotomy (15).

\section{Injection Route of Tracers}

Submucosal injection of the tracer using an endoscope is a standard procedure in the trial conducted by the Japan Society of Sentinel Node Navigation Surgery (16).

Nevertheless, several researchers have reported that there is no difference in the detection rate, mean number of SLN, and sensitivity of the SLN biopsies between submucosal and subserosal injection $(17,18)$.

\section{Operative Technique to Retrieve SLN}

Two techniques to retrieve SLN have been reported: the pickup method and lymphatic basin dissection (LBD). The pick-up method is a very popular method for breast cancer and melanoma, but it is not applicable to GC (19). In the pick-up method, hot node or nodes are dissected, but in LBD, not only hot node also cold nodes are dissected. Kelder et al. have demonstrated that intra-operative accuracy for detecting SLN metastasis is 50\% with node picking versus $92.3 \%$ with LBD (20).

\section{Clinical Results}

Radioguided SLN mapping is an accurate diagnostic procedure for detecting lymph node metastasis in patients with clinical T12NO GC. Since the main purpose of introducing this technology 
Table 1. Summary of the clinical results of the studies

\begin{tabular}{|c|c|c|c|c|c|}
\hline Reference & Year & $\mathbf{N}$ & Detection rate (\%) & Sensitivity (\%) & Result \\
\hline Niihara M et al. (28) & 2016 & 385 & 96.6 & 98.9 & Functional \\
\hline Jalaly NY et al. (29) & 2014 & 30 & 100 & 91.7 & Functional \\
\hline Toth D et al. (30) & 2013 & 40 & 97.4 & 95.7 & Functional \\
\hline Stojanovic D et al. (31) & 2013 & 137 & 98.2 & 100 & Functional \\
\hline Kitagawa Y et al. (25) & 2013 & 397 & 97.5 & 93 & Functional \\
\hline Dong LF et al. (32) & 2012 & 23 & 100 & 100 & Functional \\
\hline Park DJ et al. (33) & 2011 & 68 & 91.2 & 100 & Functional \\
\hline Kelder W et al. (20) & 2010 & 212 & 99.5 & 97 & Functional \\
\hline Ohdaira H et al. (34) & 2009 & 60 & 100 & 100 & Functional \\
\hline Yanagita S et al. (35) & 2008 & 160 & 98.8 & 96.7 & Functional \\
\hline Ichikura T et al. (36) & 2006 & 80 & 100 & 93 & Functional \\
\hline Arigami T et al. (37) & 2006 & 61 & 100 & 95.5 & Functional \\
\hline Nimura H et al. (38) & 2004 & 84 & 99 & 100 & Functional \\
\hline Zulfikaroglu B et al. (39) & 2005 & 32 & 97 & 100 & Functional \\
\hline
\end{tabular}

into GC surgery is to extend the indication of minimally invasive surgery for pathologically node negative cases, there is no advantage to include advanced cases for which modified less-invasive surgical approaches are not applicable. The size of the primary lesion is also an important factor to consider regarding this technique. It is difficult to cover a whole lymphatic drainage route from a larger tumor exceeding $4 \mathrm{~cm}$ (21).

Nakajo et al. (22) have suggested that T1N0 patients are possible candidates for SLN scintigraphy. They have reported high micrometastases rate even in patients that do not have suspected lymph nodes during preoperative evaluation. Similarly, Kitagawa et al. (13) have found the detection rate as 95\% and the accuracy as 98\%. Saikawa et al. (23) have evaluated the accuracy of SLN scintigraphy in 35 T1No GC patients. They have reported a $94.3 \%$ detection rate and 97\% accuracy. The only patient with false negative result had advanced GC with invasion into the proper muscular layer and vascular vessel invasion, causing destruction of normal lymphatic flow. At another view of aspect, Nakahara et al. (24) have reported the relation of body mass index (BMI) and success of preoperative lymphoscintigraphy, and they have found a significant difference between BMls of successful and unsuccessful groups. Kitagawa et al. (25) have calculated the detection rate of sentinel node with dual tracer method (Tc-99m Tin Colloid and blue dye) as 97.5\% in their large CT1 and CT2 gastric carcinoma group. Their 3 out of 4 false negative sentinel lymph node biopsies were pT2 tumors. They suggested that sentinel lymph node biopsy would be more successful in $\mathrm{T} 1$ tumors because false negative rate is higher in T2 tumors. Table 1 summarizes the clinical success of the studies.

Meta analyses results suggest that further studies are needed to confirm the best procedure and standard criteria for the clinical application of SLN mapping in GC $(26,27)$.

\section{CONCLUSION}

Gastric cancer is now one of the most suitable targets of an individualized less-invasive surgery based on the SLN concept although there are several unresolved issues. In our opinion, SLN mapping and SLN navigation surgery present a novelty individualizing the extent of lymphadenectomy for GC.

Informed Consent: Written informed consent was obtained from patient who participated in this case.

Peer-review: Externally peer-reviewed.

Author Contributions: Concept - B.Z., O.K.; Design - All of authors; Supervision - O.K., M.M.O.; Materials - All of authors; Data Collection and/or Processing - All of authors; Analysis and/or Interpretation - M.M.O., B.Z.; Literature Search - All of authors; Writing Manuscript - B.Z., C.S.; Critical Reviews - B.Z., O.K.

Conflict of Interest: No conflict of interest was declared by the authors

Financial Disclosure: The authors declared that this study has received no financial support.

\section{REFERENCES}

1. Rothbarth J, Wijnhoven B. Lymphatic dissemination and the role of sentinel lymph node biopsy in early gastric cancer. Dig Surg 2012; 29: 130-1. [CrossRef] 
2. Takahashi T, Saikawa Y, Kitagawa Y. Gastric cancer: current status of diagnosis and treatment. Cancers 2013; 5: 48-63. [CrossRef]

3. Niebling M, Pleijhuis $R$, Bastiaannet $E$, Brouwers A, van Dam G, Hoekstra H. A systematic review and meta-analyses of sentinel lymph node identification in breast cancer and melanoma, a plea for tracer mapping. Eur J Surg Oncol 2016; 42: 466-73. [CrossRef]

4. Giuliani A, Miccini M, Basso L. Extent of lymphadenectomy and perioperative therapies: two open issues in gastric cancer. World J Gastroenterol 2014; 20: 3889-904. [CrossRef]

5. Association JGC. Japanese classification of gastric carcinoma -2nd English edition-. Gastric Cancer 1998; 1: 10-24. [CrossRef]

6. Wu C, Hsiung C, Lo S, Hsieh M, Shia L, Whang-Peng J. Randomized clinical trial of morbidity after D1 and D3 surgery for gastric cancer. $\mathrm{Br}$ J Surg 2004; 91: 283-7. [CrossRef]

7. Wu CW, Hsiung CA, Lo SS, Hsieh MC, Chen JH, Li AFY, Lui WY, WhangPeng J. Nodal dissection for patients with gastric cancer: a randomised controlled trial. Lancet Oncol 2006; 7: 309-15. [CrossRef]

8. Yonemura Y, Wu CC, Fukushima N, Honda I, Bandou E, Kawamura T, et al. Randomized clinical trial of D2 and extended paraaortic lymphadenectomy in patients with gastric cancer. Int J Clin Oncol 2008; 13: 132-7. [CrossRef]

9. Hartgrink $H$, Van de Velde C, Putter H, Bonenkamp J, Klein Kranenbarg E, Songun I, et al. Extended lymph node dissection for gastric cancer: who may benefit? Final results of the randomized Dutch gastric cancer group trial. J Clin Oncol 2004; 22: 2069-77. [CrossRef]

10. Songun I, Putter H, Kranenbarg EMK, Sasako M, van de Velde CJ. Surgical treatment of gastric cancer: 15-year follow-up results of the randomised nationwide Dutch D1D2 trial. Lancet Oncol 2010; 11:439-49. [CrossRef]

11. Degiuli M, Sasako M, Ponti A. Morbidity and mortality in the Italian Gastric Cancer Study Group randomized clinical trial of D1 versus D2 resection for gastric cancer. Br J Surg 2010; 97: 643-9. [CrossRef]

12. Maruyama K, Sasako M, Kinoshita T, Sano T, Katai H. Can sentinel node biopsy indicate rational extent of lymphadenectomy in gastric cancer surgery? Langenbecks Arch Surg 1999; 384: 149-57. [CrossRef]

13. Kitagawa Y, Ohgami M, Fujii H, Mukai M, Kubota T, Ando N, et al. Laparoscopic detection of sentinel lymph nodes in gastrointestinal cancer: a novel and minimally invasive approach. Ann Surg Oncol 2001; 8: 86S-9S. [CrossRef]

14. Kitagawa Y, Fujii H, Mukai M, Kubo A, Kitajima M. Sentinel lymph node mapping in esophageal and gastric cancer. Selective sentinel lymphadenectomy for human solid cancer. Cancer Treat Res 2005: 123-39. [CrossRef]

15. Peparini N. Digestive cancer surgery in the era of sentinel node and epithelial-mesenchymal transition. World J Gastroenterol 2013; 19: 8996-9002. [CrossRef]

16. Kitagawa Y, Fujii H, Mukai M, Kubo A, Kitajima M. Current status and future prospects of sentinel node navigational surgery for gastrointestinal cancers. Ann Surg Oncol 2004; 11:242S-4S. [CrossRef]

17. Lee J, Ryu K, Kim C, Kim S, Choi I, Kim Y, et al. Comparative study of the subserosal versus submucosal dye injection method for sentinel node biopsy in gastric cancer. Eur J Surg Oncol 2005; 31: 965-8. [CrossRef]

18. Yaguchi Y, Ichikura T, Ono S, Tsujimoto H, Sugasawa H, Sakamoto $N$, et al. How should tracers be injected to detect for sentinel nodes in gastric cancer-submucosally from inside or subserosally from outside of the stomach? J Exp Clin Cancer Res 2008; 27: 79. [CrossRef]
19. Fujimura T, Fushida S, Tsukada T, Kinoshita J, Oyama K, Miyashita T, et al. A new stage of sentinel node navigation surgery in early gastric cancer. Gastric Cancer 2015; 18: 210-7. [CrossRef]

20. Kelder W, Nimura H, Takahashi N, Mitsumori N, Van Dam G, Yanaga K. Sentinel node mapping with indocyanine green (ICG) and infrared ray detection in early gastric cancer: an accurate method that enables a limited lymphadenectomy. Eur J Surg Oncol 2010; 36: 552-8. [CrossRef]

21. Takeuchi H, Kitagawa Y. Sentinel node navigation surgery in upper gastrointestinal cancer: what can it teach us? Ann Surg Oncol 2011; 18: 1812. [CrossRef]

22. Nakajo A, Natsugoe S, Ishigami S, Matsumoto M, Nakashima S, Hokita $\mathrm{S}$, et al. Detection and prediction of micrometastasis in the lymph nodes of patients with pNO gastric cancer. Ann Surg Oncol 2001; 8: 158-62. [CrossRef]

23. Saikawa Y, Otani Y, Kitagawa Y, Yoshida M, Wada N, Kubota T, et al. Interim results of sentinel node biopsy during laparoscopic gastrectomy: possible role in function-preserving surgery for early cancer. World J Surg 2006; 30: 1962-8. [CrossRef]

24. Nakahara T, Kitagawa Y, Yakeuchi H, Fujii H, Suzuki T, Mukai M, et al. Preoperative lymphoscintigraphy for detection of sentinel lymph node in patients with gastric cancer-initial experience. Ann Surg Oncol 2008; 15: 1447-53. [CrossRef]

25. Kitagawa Y, Takeuchi H, Takagi Y, Natsugoe S, Terashima M, Murakami $N$, et al. Sentinel node mapping for gastric cancer: a prospective multicenter trial in Japan. J Clin Oncol 2013; 31: 3704-10. [CrossRef]

26. Ryu KW, Eom BW, Nam BH, Lee JH, Kook MC, Choi IJ, et al. Is the sentinel node biopsy clinically applicable for limited lymphadenectomy and modified gastric resection in gastric cancer? A meta-analysis of feasibility studies. J Surg Oncol 2011; 104: 578-84. [CrossRef]

27. Wang Z, Dong ZY, Chen JQ, Liu JL. Diagnostic value of sentinel lymph node biopsy in gastric cancer: a meta-analysis. Ann Surg Oncol 2012; 19: 1541-50. [CrossRef]

28. Niihara M, Takeuchi H, Nakahara T, Saikawa Y, Takahashi T, Wada N, et al. Sentinel lymph node mapping for 385 gastric cancer patients. J Surg Res 2016; 200: 73-81. [CrossRef]

29. Jalaly NY, Valizadeh N, Azizi S, Kamani F, Hassanzadeh M. Sentinel lymph node mapping and biopsy using radioactive tracer in gastric cancer. ANZ J Surg 2014; 84: 454-8. [CrossRef]

30. Tóth D, Török M, Kincses Z, Damjanovich L. Prospective, comparative study for the evaluation of lymph node involvement in gastric cancer: Maruyama computer program versus sentinel lymph node biopsy. Gastric Cancer 2013; 16:201-7. [CrossRef]

31. Symeonidis D, Koukoulis G, Tepetes K. Sentinel node navigation surgery in gastric cancer: Current status. World J Gastrointest Surg 2014; 6: 88. [CrossRef]

32. Dong $L F$, Wang $L B$, Shen JG, XU CY. Sentinel lymph node biopsy predicts lymph node metastasis in early gastric cancer: a retrospective analysis. Dig Surg 2012; 29: 124-9. [CrossRef]

33. Park DJ, Kim HH, Park YS, Lee HS, Lee WW, Lee HJ, et al. Simultaneous indocyanine green and 99mTc-antimony sulfur colloid-guided laparoscopic sentinel basin dissection for gastric cancer. Ann Surg Oncol 2011; 18: 160-5. [CrossRef]

34. Ohdaira H, Nimura H, Takahashi N, Mitsumori N, Kashiwagi H, Narimiya $\mathrm{N}$, et al. The possibility of performing a limited resection and a lymphadenectomy for proximal gastric carcinoma based on sentinel node navigation. Surg Today 2009; 39: 1026. [CrossRef] 
35. Yanagita S, Natsugoe S, Uenosono Y, Kozono T, Ehi K, Arigami T, et al. Sentinel node micrometastases have high proliferative potential in gastric cancer. J Surg Res 2008; 145: 238-43. [CrossRef]

36. Ichikura T, Chochi K, Sugasawa H, Yaguchi Y, Sakamoto N, Takahata $R$, et al. Individualized surgery for early gastric cancer guided by sentinel node biopsy. Surgery 2006; 139: 501-7. [CrossRef]

37. Arigami T, Natsugoe S, Uenosono Y, Mataki Y, Ehi K, Higashi H, et al. Evaluation of sentinel node concept in gastric cancer based on lymph node micrometastasis determined by reverse transcription-polymerase chain reaction. Ann Surg 2006; 243: 341-7. [CrossRef]
38. Nimura H, Narimiya N, Mitsumori N, Yamazaki Y, Yanaga K, Urashima M. Infrared ray electronic endoscopy combined with indocyanine green injection for detection of sentinel nodes of patients with gastric cancer. Br J Surg 2004; 91:575-9. [CrossRef]

39. Zulfikaroglu B, Koc M, Ozmen MM, Kucuk NO, Ozalp N, Aras G. Intraoperative lymphatic mapping and sentinel lymph node biopsy using radioactive tracer in gastric cancer. Surgery 2005; 138: 899-904. [CrossRef]

\title{
DERLEME-ÖZET
}

Turk J Surg 2020; 36 (4): 393-398

\section{Mide kanseri cerrahisinde lenf bezi haritalaması: güncel durum ve yeni ufuklar}

\author{
Barış Zülfikaroğlư ${ }^{1}$, Özlem Küçük ${ }^{2}$, Çigdem Soydall ${ }^{2}$, Mahir Özmen ${ }^{3}$ \\ ${ }^{1}$ Ankara Numune Eğitim ve Araştırma Hastanesi, Genel Cerrahi Kliniği, Ankara, Türkiye \\ ${ }^{2}$ Ankara Üniversitesi Tıp Fakültesi, Nükleer Tıp Anabilim Dalı, Ankara, Türkiye \\ ${ }^{3}$ İstinye Üniversitesi Tıp Fakültesi, Genel Cerrahi Anabilim Dalı, İstanbul, Türkiye
}

\section{ÖZET}

Gastrik kanser (GC), dağılımda önemli coğrafi, etnik ve sosyoekonomik farklılıklara sahip en önemli malign hastalıklardan biri olmaya devam etmektedir. Sentinel lenf nodu (SLN) haritalaması, bazı solid tümörlerde lenfatik yayılımı değerlendirmenin kabul edilen bir yoludur, gastrik lenfatik drenajın karmaşıklı̆ı bu prosedürün kullanımını engelleyebilir, tahmini doğruluk oranı genel olarak makul derecede iyidir. GC'de SLN haritalama ve navigasyon cerrahisinin mevcut durumu gözden geçirilmektedir. SLN haritalaması klinik T1 ve çapı 4 cm'den küçük tümörler ile sınırlı olmalıdır. Radyoaktif kolloid ve mavi boya ile kombinasyon SLN haritalaması standart olarak kullanılır. Kayda değer sınırlamalarına rağmen, SLN haritalaması ve SLN navigasyon cerrahisi lenfadenektomiyi kişiselleştiren bir yenilik sunmaktadır.

Anahtar Kelimeler: Lenf nodu haritası, mide kanseri, cerrahi

Doi: 10.47717/turkjsurg.2020.4932 